\title{
Evaluasi Program Pembelajaran Karakter Berbasis Revolusi Mental SMP di Kabupaten Sumbawa
}

\author{
${ }^{1}$ Roni Hartono, ${ }^{2}$ Yudi Mulyanto.
}

\begin{abstract}
1Program Studi Psikologi Fakultas Psikologi, Universitas Teknologi Sumbawa. 2Program Studi Teknik Informatika Fakultas Teknik, Universitas Teknologi Sumbawa. *Corresponding Author email: roni.hartono@uts.ac.id, yudi.mulyanto@uts.ac.id.
\end{abstract}

\begin{tabular}{ll}
\hline \multirow{2}{*}{$\begin{array}{l}\text { Diterima } \\
\text { Bulan September }\end{array}$} & Abstrak \\
\cline { 2 - 3 } 2019 & $\begin{array}{l}\text { Tujuan penelitian ini adalah untuk: melihat sejauh mana peran agama dan peran lingkungan } \\
\text { dalam pendidikan karakter di sekolah menengah pertama di Kabupaten Sumbawa. Metode } \\
\text { penelitian yang digunakan adalah model evaluasi dengan menggunakan analisis korelasi } \\
\text { kedua variabel yaitu agama dan lingkungan. Data penelitian diperoleh dari instrumen agama }\end{array}$ \\
Diterbitkan & fan lingkungan yang validitasnya dibuktikan menggunakan validitas tampang dan validitas \\
Bulan Oktober & pendidikan karakter berbasis lingkungan adalah 3,64 yang berarti pendidikan karakter \\
2019 & berbasis lingkungan berada dalam kategori baik. Hasil analisis data instrumen pendidikan \\
& karakter berbasis agama adalah 3,24 yang berarti pendidikan karakter berbasis lingkungan \\
Keyword: & berada dalam kategori baik. hasil uji korelasi antara kedua variabel bernilai positif dengan \\
Evaluasi, Karakter, & nilai korelasi sebesar 0,221 dengan sig. (p hitung) = 0,0001 atau p<0,05 yang berarti \\
hebungan yang terjadi antara kedua variabel bersifat signifikan.
\end{tabular}

Revolusi Mental

\section{PENDAHULUAN}

Bangsa Indonesia merupakan sebuah bangsa yang majemuk dan beragam, yang terdiri dari beragam suku bangsa, agama, adat istiadat serta kebiasaan yang beragam. Hal tersebut dikarenakan wilayah Indonesia yang terdiri dari ribuan pulau, ratusan suku bangsa, keberagaman agama dan kepercayaan, serta adat istiadat. Setiap suku bangsa di Indonesia memiliki kekhasan adat istiadat tersendiri yang berbeda dari suku bangsa sehingga memiliki karakter yang berbeda. Penguatan karakter bangsa menjadi poin kedelapan dalam Nawacita yang dicanangkan Presiden Joko Widodo melalui Gerakan Nasional Revolusi Mental (GNRM). Komitmen ini ditindaklanjuti dengan arahan Presiden kepada Menteri Pendidikan dan Kebudayaan untuk mengutamakan dan membudayakan pendidikan karakter di dalam dunia pendidikan.

Pemerintah telah menyadari adanya bahaya yang timbulkan oleh lemahnya karakter masyarakat. Usaha pemerintah dalam mewujudkan masyarakat yang pandai dan memiliki karakter yang kuat dicanangkan sebagai salah satu program pembangunan nasional. Atas dasar ini, Kementerian Pendidikan dan Kebudayaan mencanangkan Gerakan Penguatan Pendidikan Karakter (PPK) secara bertahap mulai Tahun Ajaran 2016. Gerakan PPK sebagai sebuah gerakan nasional menjadikan satuan pendidikan sebagai sarana strategisnya. Kendala yang mungkin dihadapi mencakup antara lain keragaman lokasi dari daerah perkotaan hingga pedesaan dan terpencil, infrastruktur, pendidik dan tenaga kependidikan, serta dukungan ekosistem pendidikan yang bersifat multikultural, dengan beragam latar belakang, adat, dan nilai yang berbeda-beda.

Karakter bangsa indonesia saat ini memang dalam kondisi kritis. Pengembangan pendidikan karakter menjadi sesuatu yang harus dilaksanakan. Adanya kesenjangan yang terjadi antara kenyataan dilapangan dengan harapan yang terjadi di lapangan harus segera diatasi. Di sisi lain kesenjangan terhadap berbagai situasi prilaku remaja yang sudah menjauh dari ahlak mulia dan budi luhur semakin tampak pada tindakan remaja saat ini. Tindakan tawuran anak sekolah, tawuran antar kampung, tindakan asusila sering terjadi di sekitar kita. Maraknya berita di berbagai media massa tentang tauran remaja, Perselisihan antar suku, dan penganiayaan orang tua terhadap anak kandungnya, sodomi, pemerkosaan dan penyalagunaan narkoba sebagai salah satu cara penyelesaian atas masalah-masalah yang dihadapi oleh para remaja dan orang tua dewasa ini menjadi suatu keprihatinan, bukan hanya keprihatinan satu pihak tapi sudah menjadi keprihatinan bangsa.

Kenyataan tersebut juga menyebabkan bangsa indonesia menjadi salah satu negara dengan tingkat kekerasan paling tinggi. Terpuruknya moral bangsa ini disebabkan oleh terpuruknya moral para generasi muda karena lemahnya karakter yang dimiliki pada penerus bangsa kita, sehingga belum 
mampu menghadapi era globalisasi dan pengaruhpengaruhnya. Fenomena ini menunjukkan bahwa virus yang melemahkan karakter bangsa telah banyak mengjangkiti orang-orang yang memiliki kapasitas kognitif yang cukup.

Melihat semua kenyataan tersebut semua pihak yang bergelut dan berkecimpung dalam dunia pendidikan seperti para pendidik, aktivis pendidikan, konsultan pendidikan, orang tua dituntut untuk segera menentukan sikap dan pilihan, mana yang harus didahulukan antara pendidikan karakter atau pendidikan akademik semata. Mengutip kalimat dari Bung Karno, salah satu pendiri bangsa indonesia dan merupakan presiden pertama negara Republik Indonesia (dalam Asmani, et; al, 2011) beliau mengatakan bahwa "Bangsa ini harus dibangun dengan mendahulukan pembangunan karakter inilah yang akan membuat Indonesia menjadi bangsa yang besar, maju dan jaya serta bermartabat. Jika pembangunan karakter tidak dilakukan, maka bangsa indonesia akan menjadi bangsa kuli.'

Bangsa Indonesia mengalami krisis dalam berbagai bidang seperti dalam bidang pendidikan, ekonomi, sosial dan budaya. Kunci dari semua krisis ini adalah terletak pada kurangnya kualitas sumber daya manusia, yang didasari oleh lemahnya karakter yang dimiliki. Pengembangan pendidikan di tingkat dasar (SD-SMU) sudah dilakukan sejak lama di negeri kita. Usaha yang dilakukan selama ini cenderung fokus pada peningkatan akses memperoleh pendidikan dasar dan peningkatan pada aspek akademik. Namun dari segi kualitas ternyata masih banyak temuan-temuan timpangnya kualitas pendidikan antara sekolah yang satu dengan yang lainnya.

Temuan-temuan atau kasus-kasus di atas, menunjukkan betapa terpuruknya dan lemahnya karakter bangsa ini, terutama di dunia pendidikan, penanaman nilai-nilai positif yang harusnya dilakukan oleh para guru atau pengajar justru dirusak oleh mereka dengan melakukan kecurangan-kecurangan. Sekolah sebagai salah satu sarana pendidikan memiliki fungsi bukan hanya menciptakan para peserta didiknya yang cerdas tapi juga berakhlak, kreatif, bertanggung jawab, inovatif dan mampu menumbuhkan kepenasaranan Intelektual pada peserta didik atau menumbuhkan rasa ingin tahu dan semangat pembelajar. hal inilah yang membuat peneliti mencoba mengangkat judul penelitian tentang evaluasi implementasi pendidikan karakter berbasis revolusi mental sekolah menengah pertama di Kabupaten Sumbawa.

\section{LANDASAN TEORI}

Evaluasi

Secara harfiah evaluasi berasal dari bahasa Inggris yaitu evaluation yang akar katanya berasal dari kata value dan jika diterjemahkan ke dalam bahasa Indonesia berarti nilai atau penilaian. Berdasarkan defenisi di atas dapat disimpulkan bahwa evaluasi adalah suatu tindakan atau proses untuk menentukan nilai dari sesuatu. Selanjutnya menurut Alkin (2011:09) “ evaluation is judging the merit worth of an entity", makna dari pendapat tersebut adalah bahwa evaluasi merupakan keputusan kebernilaian jasa dari satu kesatuan. Maka, evaluasi itu tidak bisa dilepaskan sebagai sebuah nilai dalam satu program maupun apa yang menjadi kajian dari evaluasi.

Dapat ditarik kesimpulan bahwa evaluasi merupakan proses menggambarkan, memperoleh, melaporkan secara deskriptif dan evaluatif tentang manfaat beberapa obyek, nilai dan makna, untuk memandu pengambilan keputusan, akuntabilitas, dukungan, menyebarkan praktek-praktek efektif, dan meningkatkan pemahaman tentang fenomena. Menurut Guba dan Lincoln dalam Arifin (2013:5) evaluasi adalah suatu proses untuk menggambarkan peserta didik dan menimbangnya dari segi nilai dan arti. Mardapi (2012:26) menjelaskan bahwa evaluasi adalah informasi tentang pelaksanaan dan keberhasilan suatu program yang selanjutnya digunakan untuk menentukan kebijakan berikutnya. Alkin (2011:17) menjelaskan;" the need professional evaluation is disciplined inquiry directed toward a particular program and potential decision that might be made about it", makna dari penjelasan di atas adalah kebutuhan dari evaluasi profesional adalah disiplin penyelidikan diarahkan ke sebuah program tertentu dan keputusan potensial yang mungkin dibuat tentang hal itu. Rossi dan Freeman (1985:19) mendefenisikan ; "evaluation research is systematic application of social research procedures in assessing the conceptualization and design, implementation, and utility of social intervention program", makna dari pernyataan ini bahwa riset evaluasi merupakan prosedur aplikasi riset sosial yang sistematis di dalam menaksir konseptualisasi desain, implementasi, dan kegunaan dari program intervensi sosial.

Dapat disimpulkan bahwa evaluasi dapat diartikan sebagai proses, dalam hal ini proses untuk mengumpulkan informasi tentang pelaksanaan dan keberhasilan suatu program yang selanjutnya digunakan untuk menentukan kebijakan apakah program tersebut berhasil, perlu dilanjutkan, dihentikan, dikembangkan, atau penelitian langsung kearah sebuah program yang nantinya bisa membuat keputusan atau kebijakan yang kuat mengenai program yang akan diteliti serta mencapai tujuan evaluasi. Seperti yang dijelaskan oleh Kaufman dan Thomas (1980:4) "evaluation may determine what is working, what is not working, what to change, and what to keep", arti 
dari pernyataan ini adalah bahwa evaluasi boleh menentukan apa yang sedang bekerja, apa yang tidak bekerja, apa yang harus berubah, dan apa yang harus dicari.

Dikemukakan juga oleh Fernandes (1984:1) "Evaluation serve two functions, the formative function evaluation is used for the improvement and development of program, in sumative function evaluation is used for accountability, selection and certification ", makna penjelasan ini bahwa evaluasi melayani dua fungsi, fungsi evaluasi formatif adalah digunakan untuk perbaikan dan pengembangan program. Pendapat di atas diperkuat penelitian Matthew Militello, Jason Schweid \& Stephen G. Sireci (2010:49-50) tentang penggunaan sistem penilaian formative yang sangat dibutuhkan guru, administrasi sekolah, keluarga siswa, dan siswa untuk menjalankan kurikulum, pengembangan pembelajaran, dan modifikasi bahan/materi pelajaran. Tujuan penggunaan sistem penilaian formative adalah untuk mengumpulkan data yang digunakan dalam memberikan informasi pada pelaksana pendidikan dan pengambilan keputusan administratif di sekolah. Sedangkan evaluasi sumatif berguna untuk pertanggung jawaban, seleksi dan sertifikasi. Pendapat ini diperkuat oleh penelitian yang dilakukan Schildkamp dan Teddlie (2008:275-276) dimana hasil penelitiannya menemukan bahwa sekolah di Belanda dan Louisiana menggunakan model School performance feedback systems (SPFSS), penggunaan model School performance feedback systems (SPFSS) memberikan sumbangan yang signifikan ke sekolah untuk meningkatkan proses pembelajaran serta membantu pemerintah untuk melakukan evaluasi sumatif dalam menentukan bisa atau tidaknya suatu sekolah dipilih untuk mendapatkan pembiayaan dari pemerintah .

Dalam hal ini, yang menjadi tujuan utama untuk dievaluasi adalah evaluasi program dalam dunia pendidikan. Dalam UU No.20 Tahun 2003 pasal 1 ayat 21 menjelaskan evaluasi pendidikan sebagai kegiatan pengendalian, penjaminan, dan penetapan mutu pendidikan terhadap berbagai komponen pendidikan pada setiap jalur, jenjang, dan jenis pendidikan sebagai bentuk pertanggungjawaban penyelenggara pendidikan. Popham (1993:7) menyatakan; "Systematic educational evaluation consists of formal appraisal of the quality of education phenomena ", ini bermakna bahwa sistematika evaluasi pendidikan terdiri dari penilaian kualitas formal dari fenomena pendidikan. Menurut Asher (1976:197) menyatakan; "Educational evaluation is obtaining and using information for judging which altenative should be selected in making an educational decision", ini dimaknai bahwa evaluasi pendidikan adalah memperoleh dan menggunakan informasi untuk memutuskan alternatif yang mana yang akan dipilih dalam membuat keputusan pendidikan. Sedangkan yang menjadi obyek evaluasi pendidikan adalah evaluasi yang dilakukan pada siswa. Menurut Ahmann dan Glock (1981:12) “ student evaluation is a process in which a teacher commonly uses information derived from many sources to arrive at a value judgement" intisari dari pendapat di atas adalah bahwa evaluasi siswa merupakan suatu proses seorang guru biasanya menggunakan informasi yang diperoleh dari banyak sumber untuk sampai di suatu keputusan nilai.

Berdasarkan beberapa defenisi di atas dapat diambil kesimpulan bahwa evaluasi bidang pendidikan adalah penilaian mengenai nilai dan kualitas bidang pendidikan berdasarkan fenomena yang terjadi atas dasar pengumpulan informasi sistematis dalam pembuatan keputusan untuk mendukung pembelajaran yang nantinya diketahui mutu dan hasilnya. Dalam hal ini yang menjadi bagian untuk dievaluasi dalam pendidikan adalah evaluasi siswa

\section{Pendidikan Karakter}

Secara etimologis, karakter berasal dari bahasa Yunani yaitu charassein yang berarti to engrave yang artinya mengukir, melukis, memahatkan, atau menggoreskan. Menurut Kamus Besar Bahasa Indonesia (2008) Karakter merupakan sifat-sifat kejiwaan, akhlak atau budi pekerti yang membedakan seseorang dengan yang lain. Scerenco (dalam Samani M, et;al. 2011) mengatakan karakter adalah atribut atau ciri-ciri yang membentuk dan membedakan ciri pribadi, ciri etis dan kompleksitas mental dari seseorang, suatu kelompok atau bangsa. Karakter juga dapat dimaknai sebagai cara berpikir dan berprilaku yang khas tiap individu untuk hidup dan bekerjasama,baik dalam lingkup keluarga, masyarakat,bangsa dan negara (Samani, M, et;al. 2011).

Mengacu pada pengertian-pengertian di atas, karakter adalah cara berpikir dan berprilaku yang khas dari seorang individu yang membedakan dengan individu lainnya yang meliputi sifat-sifat kejiwaan, akhlak, tanggung jawab dan ketaqwaan yang merupakan ciri etis dan kompleksitas pribadi seorang individu. Dalam Policy Brief, edisi 4 juli 2011 dari Direktorat Jendral pendidikan Dasar menyatakan bahwa Pendidikan karakter adalah upaya sadar dan sungguh-sungguh yang dilakukan untuk mengembangkan karakter yang mulia dari peserta didik dengan mempraktikkan dan mengajarkan nilai-nilai moral dan pengambilan keputusan yang beradap dalam hubungan dengan sesama manusia, lingkungan dan sang pencipta. 
Menurut Noll (dalam Samani, M. Et al. 2011) pendidikan karakter dapat diartikan secara sempit dan luas. Dalam makna yang Luas pendidikan karakter mencakup hampir seluruh usaha sekolah di luar bidang akademis terutama yang bertujuan untuk membantu siswa tumbuh menjadi seseorang yang memiliki rakter yang baik. Dalam makna yang sempit pendidikan karakter dimaknai sebagai sejenis pelatihan moral yang merefleksikan nilai tertentu.

Menurut Screenco (dalam Samani, M, et;al.2011), pendidikan karakter dapat dimaknai sebagai upaya yang sungguh-sungguh dengan cara mana ciri kepribadian positif dikembangkan, didorong dan diberdayakan melalui keteladanan, kajian sejarah para pemikir bijak serta praktik emulasi (usaha yang maksimal untuk mewujudkan hikmah dari apa-apa yang diamati dan dipelajari).

Dari pengertian-pengertian di atas dapat disimpulkan bahwa pendidikan karakter adalah proses pemberian tuntunan kepada peserta didik untuk menjadi manusia seutuhnya yang berkarakter dalam dimensi hati, pikir, raga, serta rasa dan karsa. Pendidikan karakter dapat juga dimaknai sebagai upaya yang terencana untuk menjadikan peserta didik mengenal, peduli dan menginternalisasi nilai-nilai sehingga peserta didik berprilaku sebagai insan kamil.

\section{METODE PENELITIAN}

Ditinjau dari jenis dan sumber data yang digunakan, penelitian ini menggunakan pendekatan campuran deskriptif kuantitatif dan kualitatif. Pendekatan kuantitatif digunakan untuk menjaring hasil angket berupa data-data yang diperoleh dari penyebaran angket untuk selanjutnya di analisis dengan menghitung rata-rata skor yang didapatkan dari penjumlahan skor tiap item yang diperoleh. Pendekatan kualitatif digunakan untuk menjelaskan data-data yang diperoleh melalui pendekatan kuantitatif berupa data deskriptif dalam bentuk kata-kata tertulis dan lisan dari responden yang diamati secara holistik.

Teknik penetapan sampel yang digunakan sebagai sumber informasi untuk siswa adalah propotional random sampling. Adapun metode penarikan sampel ini menggunakan rumus Slovin yang bertujuan untuk proporsi siswa sebagai responden agar sampel representatif mewakili populasi siswa secara keseluruhan. Taraf signifikan yang digunakan dalam penelitian ini adalah 5\% $(0,05)$ dan galat $10 \%(0,10)$ karena mengingat penelitian ini adalah penelitian pendidikan dengan jumlah responden yang banyak sebesar 1.892 responden dan adanya keterbatasan yang dimiliki peneliti dalam melakukan penelitian serta luasnya daerah yang akan dilakukan penelitian. Adapun Rumus Slovin sebagai berikut :

$$
\mathrm{n}=\frac{\mathrm{N}}{1+\mathrm{Ne}^{2}} \ldots \ldots \ldots \ldots \ldots \ldots \ldots
$$

Dimana :

$\begin{array}{ll}\mathrm{N} & \text { : Jumlah Populasi } \\ \mathrm{n} & \text { : Jumlah Sampel } \\ \mathrm{e} & \text { : Nilai kesalahan. }\end{array}$

Berdasarkan data jumlah populasi siswa SMP Negeri secara keseluruhan yang digunakan di Kabupaten Sumbawa sebanyak 1.892 siswa, maka jumlah sampel yang dapat mewakili secara representatif dari jumlah populasi dengan menggunakan rumus Slovin adalah sebagai berikut

$$
\begin{gathered}
\mathrm{n}=\frac{1.892}{\left\{1+1.892(0,05)^{2}\right\}} \\
\mathrm{n}=\frac{1.892}{5,73} \\
\mathrm{n}=330
\end{gathered}
$$

Setelah diketahui jumlah sampel yang dapat mewakili populasi secara representatif, selanjutnya menentukan jumlah sampel secara proporsional terhadap populasi yang dapat mewakili dengan jumlah sampel menurut cluster. Sehingga jumlah sampel menurut cluster masing-masing SMP Negeri kelas VIII di Kabupaten Sumbawa adalah sebagai berikut:

$$
\begin{array}{ll}
\text { SMPN 1 Empang } & : \frac{509}{1.892} \times 330=89 \\
\text { SMPN 1 Sumbawa } & : \frac{695}{1892} \times 330=121 \\
\text { SMPN 1 Alas } & : \frac{689}{1892} \times 330=120
\end{array}
$$

\section{Validitas Instrumen}

Validitas yang digunakan dalam penelitian evaluasi program pendidikan karakter berbasis revolusi mental di Kabupaten Sumbawa adalah berupa validitas isi dan validitas konstrak. Validitas isi merupakan teknik validitas yang diestimasi melalui pengujian terhadap kelayakan dan relevansi isi tes melalui expert judgement. Validasi konstrak dalam penelitian ini dilihat dari validitas yang menunjukkan sejauh mana suatu tes mengukur suatu traid atau konstruk teoritis yang akan diukur.

Validitas isi menggunakan expert judgement yang terdiri dari 3 orang ahli yang menjadi pakar di dalam bidangnya masing-masing seperti pakar bahasa, pakar psikologi pendidikan, dan pakar psikologi klinis. Berdasarkan hasil validitas isi dari ekpert judgement diperoleh hasil dari 31 item pertanyaan dan pernyataan hanya diperoleh 1 item yang tidak valid dimana item tersebut $>0,3$ sedangkan 30 item lainnya semuanya valid karena 
berada di atas 0,3. Sedangkan Instrumen pendidikan karakter berbasis agama diperoleh hasil dari 30 item pertanyaan dan pernyataan hanya diperoleh 1 item yang tidak valid dimana item tersebut > 0,3 sedangkan 29 item lainnya semuanya valid karena berada di atas 0,3 .

Validitas Konstrak

Instrumen pendidikan karakter berbasis lingkungan

Tabel 1. Hasil KMO berbasis lingkungan

\begin{tabular}{|r|c|c|}
\hline \multicolumn{3}{|c|}{ KMO and Bartlett's Test } \\
\hline \multicolumn{2}{|c|}{$\begin{array}{r}\text { Kaiser-Meyer-Olkin Measure of } \\
\text { Sampling Adequacy. }\end{array}$} & .640 \\
\hline $\begin{array}{c}\text { Bartlett's } \\
\text { Test of } \\
\text { Sphericity }\end{array}$ & Approx. Chi-Square & 532.946 \\
\cline { 2 - 3 } & Df & 253 \\
\cline { 2 - 3 } & Sig. & .000 \\
\hline
\end{tabular}

Nilai KMO pendidikan karakter berbasis lingkungan sebesar 0,640 yang berarti bahwa analisis faktor sudah cocok untuk menganalisis matrix data yang bersangkutan. Nilai signifikansi barlett's test of sphericity memiliki keakuratan (signifikansi) yang tinggi $(\mathrm{p}<0,05)$ memberi implikasi bahwa matrix korelasi cocok untuk analisis faktor. nilai barlett's test untuk instrumen pendidikan karakter berbasis lingkungan menunjukkan nilai sebesar 532,946 dengan nilai signifikansi 0,000 sehingga dapat disimpulkan bahwa instrumen ini telah memenuhi nilai valid. persen cumulative total variance explained sebesar $65,408 \%$. Hal ini menunjukkan bahwa 23 item butir soal dari faktor karakter berbasis lingkungan dapat menjelaskan konstruk sekitar 68,823\%.

Berdasarkan nilai korelasi anti image untuk angket karakter berbasis lingkungan ada beberapa butir yang memenuhi nilai lebih besar dari 0,5 yaitu item $1,3,5,6,7,8,9,10,11,12,15,16,17$, , 19, $21,24,25,26,27,28$, dan 29, sedangkan item yang tidak memenuhi atau kurang dari 0,5 adalah item nomor 4, 13, 14, 20, 22, dan 23 sehingga item tersebut harus dikeluarkan.

Berdasarkan rotate component matrix diperoleh 10 faktor penyusun yaitu faktor kedisiplinan item 1,10,19, faktor kemandirian item 2, dan 11. faktor sinergi item 3, 12, 21. faktor kreatif dan inovatif item 25 . faktor nasionalisme item 5 dan 24. faktor internasionalisme item 6 dan 15. Faktor kasih sayang item 7, 16, dan 29. Faktor kritis item 8, 17, 26 serta faktor etos kerja item 9, 8, 27 dan 28.

Instrumen pendidikan karakter berbasis agama dari penilaian siswa.
Tabel 2. Hasil KMO berbasis agama

\begin{tabular}{|c|c|c|}
\hline \multicolumn{3}{|c|}{ KMO and Bartlett's Test } \\
\hline \multicolumn{2}{|c|}{$\begin{array}{c}\text { Kaiser-Meyer-Olkin Measure of } \\
\text { Sampling Adequacy. }\end{array}$} & .633 \\
\hline \multirow{2}{*}{$\begin{array}{c}\text { Bartlett's Test of } \\
\text { Sphericity }\end{array}$} & $\begin{array}{c}\text { Approx. Chi- } \\
\text { Square }\end{array}$ & 472.681 \\
\cline { 2 - 3 } & Df & 210 \\
\cline { 2 - 3 } & Sig. & .000 \\
\hline
\end{tabular}

Nilai KMO instrumen pendidikan karakter berbasis agama sebesar 0,633 Nilai barlett's test untuk instrumen pendidikan karakter berbasis agama sebesar 472'681 dengan nilai signifikansi 0,000 sehingga dapat disimpulkan bahwa instrumen ini telah memenuhi nilai valid. Sedangkan untuk persen cumulative total variance explained kinerja guru sebesar 64,869\%. Hal ini menunjukkan bahwa 19 item butir soal dari faktor pendidikan karakter berbasis agama dapat menjelaskan konstruk sekitar 64,869\%.

Berdasarkan rotate component matrix diperoleh 7 faktor penyusun yaitu faktor ketaatan dalam beribadah item nomor 1, 8, 15, dan 22 . faktor kejujuran item nomor 30. faktor tanggung jawab item nomor 3, 10,17, dan 31. faktor visioner item nomor 4 dan nomor 11. faktor kedisiplinan item nomor 12 , 19, dan 26. faktor keadilan item nomor 13,20 , dan 27 , serta faktor keikhlasan item nomor 7 dan 14 .

Butir-butir tidak valid perlu dipertimbangkan untuk digugurkan karena tidak valid. Pengguguran tersebut akan menyisakan keseluruhan item butir yang valid yaitu semua butir item yang lebih dari $0,5(>0,5)$.

\section{Reliabilitas Instrumen}

Tabel 3. Reliabilitas karakter berbasis lingkungan

\begin{tabular}{|c|c|}
\hline \multicolumn{2}{|c|}{ Reliability Statistics } \\
\hline $\begin{array}{c}\text { Cronbach's } \\
\text { Alpha }\end{array}$ & N of Items \\
\hline .664 & 23 \\
\hline
\end{tabular}


Hasil analisis reliabilitas instrumen pendidikan karakter berbasis lingkungan berdasarkan penilaian siswa (lampiran) menunjukkan angka sebesar 0,664 setelah dibandingkan dengan koefisien reliabilitas suatu instrumen dikatakan reliabel jika memiliki nilai koefisien Alpha sekurang-kurangnya 0,60. Maka, jika 0,664 lebih besar dari 0,60 bisa dikatakan instrumen penilaian kinerja guru yang didasari pada penilaian siswa adalah reliabel.

Pendidikan karakter berbasis agama berdasarkan penilaian siswa

Tabel 4. Reliabilitas karakter berbasis agama

\begin{tabular}{|c|c|}
\hline \multicolumn{2}{|c|}{ Reliability Statistics } \\
\hline $\begin{array}{c}\text { Cronbach's } \\
\text { Alpha }\end{array}$ & N of Items \\
\hline .715 & 19 \\
\hline
\end{tabular}

Hasil analisis reliabilitas instrumen pendidikan karakter berbasis agama berdasarkan penilaian siswa menunjukkan angka sebesar 0,715 lebih besar dari 0,60 bisa dikatakan instrumen karakter dipengaruhi agama yang didasari pada penilaian siswa adalah reliabel.

\section{HASIL DAN PEMBAHASAN}

\section{Hasil Penelitian \\ Pendidikan karakter berbasis lingkungan}

Hasil penelitian mengenai kualitas pendidikan karakter berbasis lingkungan SMP di Kabupaten Sumbawa diuraikan dalam sub-komponen penyusun utama komponen pendidikan karakter berbasis lingkungan, dimana diperoleh hasil bahwa Aspek kedisiplinan sebesar 3,9 termasuk dalam kriteria baik. Aspek kemandirian sebesar 3,5 termasuk dalam kriteria baik. Aspek sinergi sebesar 3,5 termasuk dalam kriteria baik. Aspek kreatif dan inovatif sebesar 3,4 termasuk dalam kriteria baik. Aspek nasionalisme sebesar 3,7 termasuk dalam kriteria baik. Aspek internasionalisme sebesar 3,7 termasuk dalam kriteria baik. Aspek kasih sayang dan kepedulian sebesar 3,7 termasuk dalam kriteria baik. Aspek kritis sebesar 3,8 termasuk dalam kriteria baik , serta aspek etos kerja sebesar 3,6 termasuk dalam kriteria baik.

Berdasarkan uraian di atas, dalam pendidikan karakter berbasis lingkungan terdapat sembilan aspek yaitu kedisiplinan, kemandirian, sinergi, kreatif dan inovatif, nasionalisme, internasionalisme, kasih sayang dan kepedulian, kritis, dan etos kerja. Dari hasil analisis data keseluruhan instrumen pendidikan karakter berbasis lingkungan adalah 3,64 yang berarti pendidikan karakter berbasis lingkungan SMP
Negeri di Kabuten Sumbawa berada dalam kategori baik.

Hasil ini sesuai dengan tujuan pendidikan nasional yang mengarahkan peserta didik secara aktif mengembangkan potensi dirinya untuk memiliki kekuatan spiritual keagamaan, pengendalian diri, kepribadian, kecerdasan, akhlak mulia, serta keterampilan yang diperlukan dirinya, masyarakat, bangsa dan negara (UU No.20 Tahun 2003). Dalam Implementasinya semua pendidikan karakter di Sumbawa dikembangkan dalam penerapan pendidikan dasar seperti Agama, Pendidikan Pancasila Dan Kewarganegaraan serta Bahasa Indonesia.

Selain itu didukung juga penelitian yang dilakukan Azizah dan Marzuki (2018) yang mengatakan bahwa karakter utama yang terdapat dalam pendidikan Kewarganegaraan yaitu nasionalis, kepatuhan pada aturan sosial, menghargai keberagaman, kesadaran akan hak dan kewajiban diri dan orang lain, bertanggung jawab, berpikir logis, kritis, kreatif dan inovatif, serta kemandirian. Didukung juga penelitian Safitri (2017) yang menemukan bahwa Lingkungan yang kondusif dapat membantu perkembangan anak karena keadaan dan suasana dapat mendukung penanaman karakter .

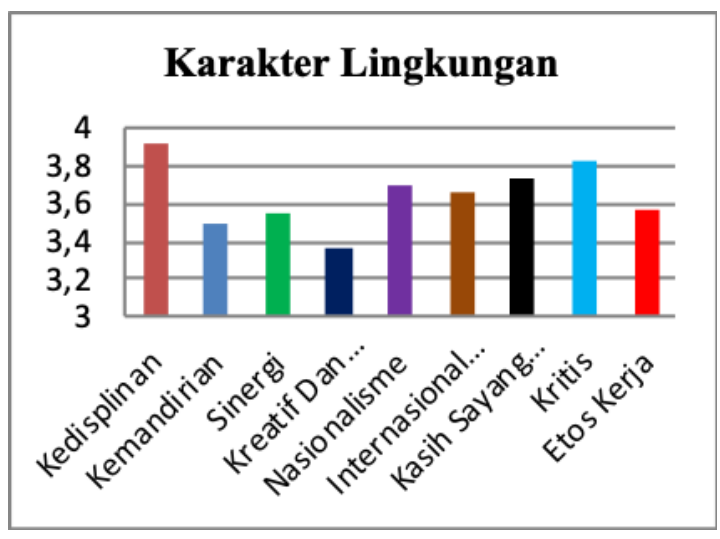

Gambar.1. hasil evaluasi karakter berbasis lingkungan

\section{Pendidikan karakter berbasis agama}

Hasil penelitian mengenai kualitas pendidikan karakter berbasis agama SMP di Kabupaten Sumbawa diuraikan dalam sub-komponen penyusun utama komponen pendidikan karakter berbasis agama. diproleh hasil sebagai berikut.

Aspek ketaatan dalam beribadah dimana ratarata hasil analisis instrumen ketaatan dalam beribadah adalah 3,24 termasuk dalam kriteria baik. Aspek kejujuran dimana rata-rata hasil analisis instrumen kejujuran adalah 4,11 termasuk dalam kriteria baik. Aspek tanggung dimana rata- 
rata hasil analisis instrumen tanggung jawab adalah 3,14 termasuk dalam kriteria baik. Aspek visioner dimana rata-rata hasil analisis instrumen visioner adalah 3,14 termasuk dalam kriteria baik. Aspek etos kerja dimana rata-rata hasil analisis instrumen kedisiplinan adalah 3,01 termasuk dalam kriteria baik. Aspek keadilan dimana rata-rata hasil analisis instrumen keadilan adalah 3,57 termasuk dalam kriteria baik. Aspek keikhlasan dimana setelah dibandingkan dengan kriteria pembanding termasuk dalam kriteria baik.

Berdasarkan uraian di atas, dalam pendidikan karakter berbasis agama terdapat tujuh aspek yaitu ketaatan dalam beribadah, kejujuran, tanggung jawab, visioner, kedisiplinan, keadilan, dan keikhlasan. Dari hasil analisis data keseluruhan instrumen pendidikan karakter berbasis agama adalah 3,24 yang berarti pendidikan karakter berbasis lingkungan SMP Negeri di Kabuten Sumbawa berada dalam kategori baik.

hasil di atas sesuai dengan fungsi pendidikan yaitu mengembangkan kemampuan dan membentuk watak serta peradaban bangsa yang bermartabat dalam rangka mencerdaskan kehidupan bangsa, bertujuan untuk berkembangnya potensi peserta didik agar menjadi manusia yang beriman dan bertakwa kepada Tuhan Yang Maha Esa, berakhlak mulia, sehat, berilmu, cakap, kreatif, mandiri, dan menjadi warganegara yang demokratis serta bertanggung jawab (UU No.20 Tahun 2003). hasil penelitian ini didukung juga penelitian yang dilakukan oleh ma'mun (2016) menyimpulkan bahwa Masyarakat Indonesia yang mayoritas memeluk agama Islam, idealnya mampu menjadikan Agama Islam sebagai basis pendidikan karakter. Dimana di dalam ajaran Islam, istilah karakter lebih dikenal dengan sebutan akhlak. Dalam perspektif Islam, karakter atau akhlak mulia merupakan buah yang dihasilkan dari proses penerapan syariah (ibadah dan muamalah) yang dilandasi oleh pondasi aqidah yang kokoh.

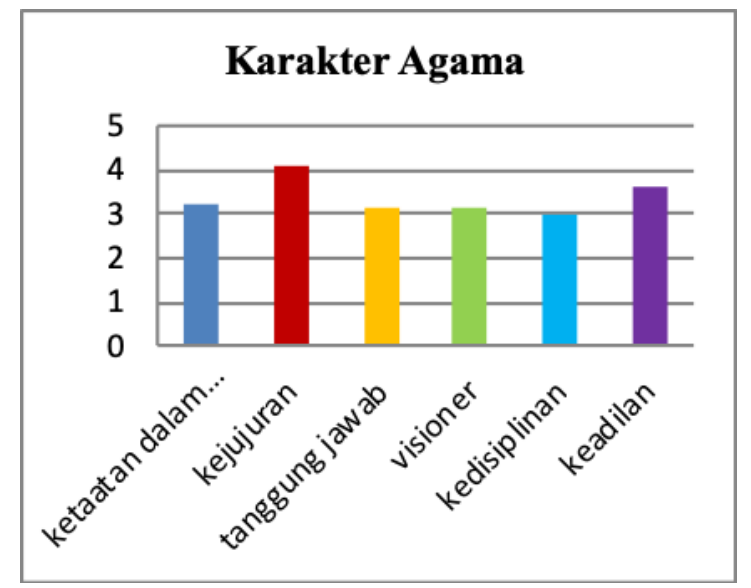

\author{
Gambar.1. hasil evaluasi karakter berbasis \\ agama
}

Hasil Analisis

Tabel 5. Reliabilitas karakter berbasis agama

\begin{tabular}{|c|c|c|c|}
\hline \multicolumn{4}{|c|}{ Correlations } \\
\hline & & lingkungan & agama \\
\hline \multirow[t]{3}{*}{ lingkungan } & $\begin{array}{l}\text { Pearson } \\
\text { Correlation }\end{array}$ & 1 & $.221^{* *}$ \\
\hline & Sig. (2-tailed) & & .000 \\
\hline & $\mathrm{N}$ & 300 & 300 \\
\hline \multirow[t]{3}{*}{ agama } & $\begin{array}{l}\text { Pearson } \\
\text { Correlation }\end{array}$ & $.221^{* *}$ & 1 \\
\hline & Sig. (2-tailed) & .000 & \\
\hline & $\mathrm{N}$ & 300 & 300 \\
\hline
\end{tabular}

Berdasarkan hasil uji korelasi, diketahui bahwa hubungan antara kedua variabel bernilai positif dengan nilai korelasi sebesar 0,221 dengan sig. ( $\mathrm{p}$ hitung) $=0,0001$ atau $\mathrm{p}<0,05$ yang berarti hubungan yang terjadi antara kedua variabel bersifat signifikan. Hipotesis yang diajukan dalam penelitian ini dimana terdapat hubungan antara peran agama dan lingkungan dalam pendidikan karakter berbasis revolusi mental diterima dan memiliki korelasi signifikan searah, yang menunjukkan bahwa semakin tinggi peran agama maka semakin tinggi pula kesadaran lingkungan dalam pendidikan karakter berbasis revolusi mental, dan begitupun sebaliknya. Semakin rendah peran agama maka semakin rendah pula kesadaran lingkungan dalam pendidikan karakter berbasis revolusi mental.

Hasil diatas diperkuat penelitian Firdausita (2017) yang menunjukkan bahwa pemahaman Agama berpengaruh terhadap perilaku perempuan. Hal ini menunjukkan semakin baik tingkat pemahaman Agama, maka perilaku perempuan akan lebih baik, serta lingkungan berpengaruh terhadap perilaku perempuan. Hal ini menunjukkan semakin baik lingkungan, maka perilaku perempuan itu akan lebih baik.

\section{PENUTUP}

Berdasarkan hasil penelitian yang telah dilakukan dan selanjutnya diuraikan dalam bab sebelumnya, kesimpulan yang dapat ditarik dari hasil penelitian ini adalah sebagai berikut.

Pendidikan karakter berbasis lingkungan .

Dalam pendidikan karakter berbasis lingkungan terdapat sembilan aspek yaitu kedisiplinan, 
kemandirian, sinergi, kreatif dan inovatif, nasionalisme, internasionalisme, kasih sayang dan kepedulian, kritis, dan etos kerja. Dari hasil analisis data keseluruhan instrumen pendidikan karakter berbasis lingkungan adalah 3,64 yang berarti pendidikan karakter berbasis lingkungan SMP Negeri di Kabuten Sumbawa berada dalam kategori baik.

Pendidikan karakter berbasis agama.

Dalam pendidikan karakter berbasis agama terdapat tujuh aspek yaitu ketaatan dalam beribadah, kejujuran, tanggung jawab, visioner, kedisiplinan, keadilan, dan keikhlasan. Dari hasil analisis data keseluruhan instrumen pendidikan karakter berbasis agama adalah 3,24 yang berarti pendidikan karakter berbasis lingkungan SMP Negeri di Kabuten Sumbawa berada dalam kategori baik.

3. Hubungan karakter berbasis lingkungan dengan karakter berbasis agama dalam pendidikan berbasis revolusi mental

Berdasarkan hasil uji korelasi, diketahui bahwa hubungan antara kedua variabel bernilai positif dengan nilai korelasi sebesar 0,221 dengan sig. ( $p$ hitung) $=0,0001$ atau $\mathrm{p}<0,05$ yang berarti hubungan yang terjadi antara kedua variabel bersifat signifikan. Hipotesis yang diajukan dalam penelitian ini dimana terdapat hubungan antara peran agama dan lingkungan dalam pendidikan karakter berbasis revolusi mental diterima dan memiliki korelasi signifikan searah, yang menunjukkan bahwa semakin tinggi peran agama maka semakin tinggi pula kesadaran lingkungan dalam pendidikan karakter berbasis revolusi mental, dan begitupun sebaliknya. Semakin rendah peran agama maka semakin rendah pula kesadaran lingkungan dalam pendidikan karakter berbasis revolusi mental.

\section{REFERENSI}

Ahmann, J. S., \& Glock. M. D. (1981). Evaluating student progress: principles of test and measurments. Massachusetts: Allyn and Bacon.

Alkin, M. C. (2011). Evaluation essential: from A to Z. New York: Guilford Press

Arifin, Z. (2013). Evaluasi pembelajaran. Bandung: Rosda Karya.

Asher, J.W. (1976). Educational Research And Evaluation Methods.Canada: Little Brown \& Company.

Alfitri dan Hambali. (2013). Integration of National Character Education and Social Conflict Resolution through Traditional Culture: A Case Study in South Sumatra Indonesia. Journal Asian Social Science, 9(12), 125135.

Allport, G.W. (1950). Personality ; a psychological interpretation. New York; Holt

Fernandes , H.J.X. (1984). Evaluation of educational programs. Jakarta: National Education, Orientation and Curricullum Development.

Kaufman, R., \& Thomas, S. (1980). Evaluation without fear. New York: New Viewpoints.

Mardapi, D. (2012). Pengukuran penilaian dan evaluasi pendidikan. Yogyakarta: Nuha Medika.

Rossi, P. H., \& Freeman, H. E. (1985). Evaluation: a systemic approach. USA: Sage Publication.

Schildkamp, K \& Teddlie, C. (2008). School performance feedback systems in the USA and in The Netherlands: a comparison. Educational Research and Evaluation: An International Journal on Theory and Practice Vol.14 issue 3.

Safitri, M. R. (2017). Penanaman pendidikan karakter berbasis kesadaran diri dalam lingkungan keluarga. Prosiding SENASGUB, Edisi Tahun 2017. E-ISSN 2599-8406. 